\title{
MENYOROTI HAK DAN KEWAJIBAN ASASI MANUSIA DALAM ASPEK EKONOMI (Sebagai Ciri Negara Kesejahteraan (Welfare State))
}

\author{
Rahma Amir \\ Fakultas Syariah Institut Agama Islam Negeri (IAIN) Palopo \\ Email : : rahmaamir.raa@gmail.com
}

\begin{abstract}
In Islamic view, common well-being management may not go against syariat Islam. To it, it is not possible in state that setting to terminological syariat Islam, E.g. do floozie localization as arena do adultery or concedes nauseating liquor sell or concedes gambling, since that conduct are prohibited conducts that prohibitted by Syariat Islam. In Islamic view, people is entitled to welfare, and honor bound advance common welfare, smartening up people life, even active deep all life aspect towards well-being all its citizen its state. Maybe no one state even at world it that don't program prosperity in economic area for its citizen. All politician make poverty remove as central issue well while campaign term, and also after as president or governance head. For state already go forward, well-being increasing problem its citizen, must not miss from its parent plan, beside approaching on another areas. But such, trick that sailed through by it can variably at each state.
\end{abstract}

Keyword: The right and obligation, Economic aspect, Wellbeing state.

\begin{abstract}
Abstrak
Dalam pandangan Islam, manajemen kesejahteraan bersama mungkin tidak bertentangan dengan syariat Islam. Untuk itu, tidak mungkin di negara yang menetapkan syariat Islam terminologis, Contoh melakukan pelokalan floozie sebagai arena melakukan perzinaan atau mengakui menjual minuman keras yang memualkan atau mengakui perjudian, karena perilaku itu adalah tindakan terlarang yang dilarang oleh Syariat Islam. Dalam pandangan Islam, orang berhak atas kesejahteraan, dan menghormati terikat kemajuan kesejahteraan bersama, membulatkan kehidupan orang, bahkan aktif dalam semua aspek kehidupan menuju kesejahteraan semua warga negaranya negaranya. Mungkin tidak ada negara bahkan di dunia ini yang tidak memprogram kesejahteraan di bidang ekonomi bagi warganya. Semua politisi menjadikan kemiskinan sebagai isu sentral dengan baik selama masa kampanye, dan juga sebagai presiden atau kepala pemerintahan. Untuk negara yang sudah maju, kesejahteraan warga negaranya semakin meningkat. Tapi hal tersebut bisa berbeda-beda di setiap daerah.
\end{abstract}

Kata kunci: Hak dan kewajiban, Aspek ekonomi, Kondisi kesejahteraan.

\section{PENDAHULUAN}

Dunia Islam sedang memasuki era budaya global dengan kemajuan teknologi informatika dan kebangkitan nasionalisme dan spiritual. Budaya global juga ditandai dengan era ekonomi baru, dan posisi hukum semakin diperlukan 
untuk mengatur- nya. ${ }^{1}$ Kondisi sosial ekonomi yang timpang dengan jurang pisah yang dalam antara golongan bermodal dan tenaga pekerja, telah menyebabkan lahirnya gerakan revolusioner buruh yang merasa tidak puas dengan kea- daan yang tidak adil itu. Hal itu menyebabkan pemerintah negara mulai menyadari perlunya negara atau pemerintah ikut aktif dalam mewujudkan kesejahteraan masyarakat. Masyarakat mulai mendesak agar negara, dalam hal ini pemerintah, aktif dalam segala aspek kehidupan masyarakat. Pemerintah negara harus mengatur keten- tuan yang menyangkut kepentingan umum, misalnya menentukan syaratsyarat kerja yang manusiawi, seperti adanya hak cuti, adanya jam istirahat, upah yang layak untuk kehidupan, jaminan pensiun dan hari tua, serta berbagai ketentuan yang bertujuan untuk menyejahterakan masyarakat. Pemerintah diwajibkan untuk meng- urusi tidak hanya pertahanan dan keamanan seperti halnya dalam negara hukum klasik, tetapi juga wajib mengurusi bidang-bidang kehidupan lainnya, seperti pendidikan, kepemudaan, perekonomian, kesehatan, lingkungan hidup, kesenian, kebudayaan dan sebagainya. Pekerjaan pemerintah negara menjadi kompleks. Itulah ciri negara kesejahteraan (welfare state). ${ }^{2}$

Meskipun demikian, masalah kemiskinan ${ }^{3}$ hingga kini terus-menerus menjadi masalah yang berkepanjangan Penyelenggaraan tugas pemerintah dalam segala aspek kehidupan itu adalah sebagian dari tugas negara hukum modern. Penyelenggaraan tugas pemerintah dalam segala aspek kehidupan itu adalah sebagian dari tugas negara hukum modern (welfare state), yakni penyelenggaraan kesejahteraan umum. Negara kesejahteraan yang pemerintahnya

\footnotetext{
${ }^{1}$ Budaya global juga antara lain disemarakkan dengan perkembangan konsep "ekonomi Islam, yang merupakan ilmu tentang manusia yang menyakini nilai-nilai hidup Islam. Karena ilmu ekonomi Islam merupakan ilmu

${ }^{2}$ Lihat Utrecht, Pengantar Hukum Administrasi, hlm. 21; Lihat juga Zallum, Sistem Pemerintahan.., hlm. 3; Azhary, Negara Hukum, h. 107-8.

${ }^{3}$ Kemiskinan adalah keadaan dimana terjadi kekurangan hal-hal yang biasa untuk dipunyai seperti makanan, pakaian, tempat berlindung dan air minum, hal-hal ini berhubungan erat dengan kualitas hidup. Kemiskinan kadang juga berarti tidak adanya akses terhadap pendidikan dan pekerjaan yang mampu mengatasi masalah kemiskinan dan mendapatkan kehormatan yang layak sebagai warga negara. Kemiskinan merupakan masalah global. Sebagian orang memahami istilah ini secara subyektif dan komparatif, sementara yang lainnya melihatnya dari segi moral dan evaluatif, dan yang lainnya lagi memahaminya dari sudut ilmiah yang telah mapan. Istilah "negara berkembang" biasanya digunakan untuk merujuk kepada negara-negara yang miskin. Satriadi dalam makalah Teori dan isu Ekonomi Politik Pembangunan https://www. facebook. com/.
} 
aktif berusaha dalam rangka peningkatan kesejah-teraan warganya baru muncul di Dunia Barat pada akhir abad ke-19 atau awal abad ke-20, sehingga bila dibandingkan dengan ajaran Islam, agaknya kita harus mengatakan Dunia Barat cukup ketinggalan. Dalam ajaran Islam, pemimpin satu kaum adalah pelayan dari kaum itu, sehingga pemimpin atau pemerintah Negara Madinah yang ditata berdasarkan hukum Islam itu adalah pelayan dari rakyat Negara Madinah. Hal ini berarti pula bahwa Negara Madinah adalah negara kesejahteraan atau negara hukum modern, bukan negara hukum klasik yang lazim dikenal dengan julukan negara jaga malam (nacbt-wakerstaat). Pemimpin atau pemerintah sebagai pelayan dari kaumnya, seperti yang diperintahkan hadits di atas, sangat sejalan dengan perintah al-Quran ketika dalam anggaran pendapatan dan belanja negara, yakni pendapatan yang berasal dari zakat dan dibelanjakan atau dialokasikan untuk orangorang fakir, orang-orang miskin, penguruspengurus zakat, para muallaf yang dibujuk hatinya, untuk (memerdekakan budak), orang-orang berutang, untuk jalan Allah dan untuk orang-orang yang sedang dalam perjalanan sebagaimana ketentuan dalam QS. at-Taubah/9 : 60 :

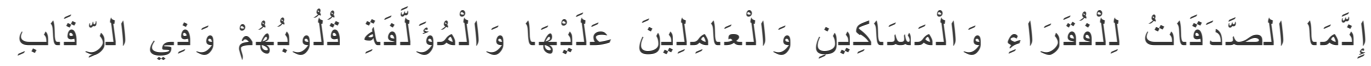

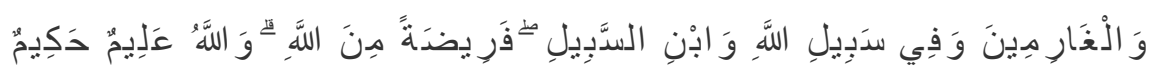

Terjemahnya: "Sesungguhnya zakat-zakat itu, hanyalah untuk orangorang fakir, orang-orang miskin, pengurus-pengurus zakat, para muallaf yang dibujuk hatinya untuk (memerdekakan budak), orangorang yang berutang untuk jalan Allah dan untuk mereka yang sedang dalam perjalanan, sebagai suatu ketetapan yang diwajibkan Allah, dan Allah Maha Mengetahui lagi Maha Bijaksana." 4

Kalau dalam hadits dan al-Qur'an tersebut adalah ketentuan normatifnya, maka dalam pelaksanaan praktiknya, dapat dilihat antara lain ketika terjadi musim paceklik di Negara Madinah pada Masa pemerintahan Amirul Mukminin Umar bin Khattab, seluruh jajarannya sibuk mengurusi rakyat Madinah yang ditimpa kelaparan. Secara normatif, kolektivisme dalam Islam sudah tampak dalam penyaluran zakat kepada delapan golongan sebagaimana dalam QS. At-Taubah/9: 
60. Kedelapan golongan yang kepadanya disalurkan zakat ini, semua bertujuan untuk kesejahteraan. Penyaluran zakat kepada orang-orang fakir, orang-orang fakir merupakan orang-orang yang sengsara hidupnya dan tidak mempunyai harta maupun tenaga untuk memenuhi penghidupannya, dengan pemberian penyaluran zakat tersebut adalah usaha mensejahterakan mereka. Sementara zakat yang diperuntukkan kepada amil atau pengurus zakat dapat dibandingkan dengan gaji pegawai karena dalam tugas pengurusan zakat itu banyak dan juga tidak mudah, maka adalah wajar apabila kepada mereka mendapat bagian dari zakat untuk kesejahteraan hidup mereka. Pemberian zakat kepada muallaf, orang-orang kafir yang ada harapan masuk Islam yang masih lemah imannya juga adalah untuk mensejahterahkan mereka, dalam pandangan Islam kesejahteraan dalam arti lahirbathin merupakan kekuatan dalam pengamalan ajaran-ajaran Islam. Memerdekakan budak sebagai suatu bagian yang dibiayai dari zakat, adalah usaha untuk mensejahterakan mereka. Bahwasanya orang-orang yang berada di bawah kekuasaan orang lain secara lahiriah tentu kehidupannya tidak sejahtera juga secara psikologi budak itu merasa rendah diri karena statusnya yang tidak setara dengan orang-orang yang merdeka. Penyediaan anggaran yang berasal dari penyaluran zakat untuk memerdekakan budak juga untuk kesejahteraan manusia secara umum. Orang-orang yang berutang karena untuk kepentingan kebaikan demi kepentingan bersama bukan untuk suatu kemaksiatan juga dapat dibantu dari penyaluran zakat untuk membayar hutangnya. Karena orang yang berutang dalam keadaan yang kurang sejahtera Perbuatan-perbuatan yang dilakukan untuk kemaslahatan bersama sesuai ajaran Islam yang diperintahkan oleh Allah swt. Ini adalah orang-orang yang berada fisabililla. Misalnya membuat pusat-pusat kesehatan masyarakat, rumah sakit, sekolah dan lain sebagainya demi untuk kepen-tingan umat. Ibnu Sabil, adalah orang-orang yang sedang dalam perjalanan yang bukan maksiat lalu mengalami kesengsaraan dalam perjalanannya. Dengan penyaluran zakat sekaligus memberikan kesejahteraan kepadanya. ${ }^{5}$ Kepedulian Islam terhadap hak-hak umatnya akan kemakmuran dan kesejahteraan hidup

${ }^{5}$ Muhammad Alim, Asas-asas Negara Hukum Modern dalam Islam (Kajian Komprehensif Islam dan Ketatanegaraan), Cetakan I (Yogyakarta: LKIS, 2010, h. 271-4 
terutama kepada kaum lemah; fakir, miskin, anak-anak yatim, begitu besar sehingga berdasar-kan kepada beberapa ayat dalam al-Qur'ean dan sunnah Rasulullah SAW.

\section{KEBEBASAN DARI KEADAAN KEMISKINAN}

Dalam doktrin Barat yang individualis, kemakmuran ekonomi dapat dicapai antara lain kalau tiap individu berjuang untuk mencapai kemajuan, sehingga kalau masing-masing bisa memenuhi kebutuhannya, maka keseluruhan warga pada akhirnya akan makmur pula. Titik utama perjuangan mereka adalah pemupukan dan pengumpulan modal atau kapital. ${ }^{6}$

Dalam pespektif Islam miskin didefinisikan dari bahasa aslinya (Arab) kata miskin terambil dari kata sakana yang berarti diam atau tenang, sedang faqir dari kata faqr yang pada mulanya berarti tulang punggung. Faqir adalah orang yang patah tulang punggungnya, dalam arti bahwa beban yang dipikulnya sedemikian berat sehingga "mematahkan" tulang punggungnya. Sebagai akibat dari tidak adanya definisi yang dikemukakan Al-Quran untuk kedua istilah tersebut, para pakar Islam berbeda pendapat dalam menetapkan tolok ukur kemiskinan dan kefakiran. Sebagian mereka berpendapat bahwa fakir adalah orang yang berpenghasilan kurang dari setengah kebutuhan pokoknya, sedang miskin adalah yang berpenghasilan di atas itu, namun tidak cukup untuk menutupi kebutuhan pokoknya. Ada juga yang mendefinisikan sebaliknya, sehingga menurut mereka keadaan si fakir relatif lebih baik dari si miskin. Sehingga dapat disimpulkan bahwa Islam memandang bahwa masalah kemiskinan adalah masalah tidak terpenuhinya kebutuhan primer secara menyeluruh. Kemiskinan adalah problem

\footnotetext{
${ }^{6}$ Bapak ekonomi Kapitalis Adam Smith membangun ajaran Kapitalisme dengan paradigma Laissez Faire. Menurut Adam Smith, setiap orang harus diberikan kebebasan untuk melakukan apa yang diinginkannya tanpa campur tangan negara. Prinsip ini mendorong mekanisme dan transaksi ekonomi, termasuk hukum perundang-undangan tunduk pada prinsip kebebasan kepemilikan dengan nilai-nilai materialistis yang "hampa" agama (sekularisme). Dengan ini manusia terpancing meraup keuntungan sebesar-besarnya (profit oriented) tidak peduli bagaimana cara memperoleh dan apa dampaknya bagi orang lain dan lingkungan. Adnan Khan, Kapitalisme di Ujung Tanduk: Tinjauan atas Krisis Global, Krisis Minyak, Krisis Pangan dan Bagaimana Sistem Ekonomi Islam Mengatasinya (The Global Credit Crunch and The Crisis of Capitalism), cet. I ( Bogor: Pustaka Thariqul Izzah,2008), h. 128. Lihat pula Mansour Fakih, Runtuhnya Teori Pembangunan dan Globalisasi (Yogyakarta: INSIST Press dan Pustaka Pelajar, 2002), h. 46.
} 
sosial. Bagi kebanyakan orang, kemiskinan merupakan masalah yang cukup merisaukan. Ia dianggap sebagai penyakit sosial yang paling dahsyat dan menjadi musuh utama negara. ${ }^{7}$ Kemiskinan atau kefakiran adalah suatu fakta, yang dilihat dari kacamata dan sudut mana pun seharusnya mendapat pengertian yang sesuai dengan realitasnya. Peradaban Barat Kapitalis, pengembangan sistem ekonomi Kapitalis, memiliki gambaran/fakta tentang kemiskinan yang berbeda. Mereka menganggap bahwasannya kemiskinan adalah ketidak-mampuan untuk memenuhi kebutuhan-kebutuhan atas barang ataupun jasa secara mutlak. Karena kebutuhan berkembang seiring dengan berkembang dan majunya produk-produk barang ataupun jasa, maka mereka menganggap usaha pemenuhan kebutuhan atas barang dan jasa itu pun mengalami perkembangan dan perbedaan. Kemiskinan bukan saja dilihat sebagai fenomena ekonomi semata-mata, tetapi juga sebagai masalah sosial dan politik. Karena dahsyatnya bahaya kemiskinan, membasmi kemiskinan dianggap sebagai jihad. ${ }^{8}$ Secara umum, kemiskinan mempunyai empat dimensi pokok, yaitu; kurangnya kesempatan (lack of opportunity); rendahnya kemampuan (low of capabilities); kurangnya jaminan (low-level of security); dan ketidakberdayaan (low of capacity or empowerment). Lazimnya kemiskinan diukur dengan garis kemiskinan (poverty line). Kemiskinan tidak saja mengakibatkan penyakit busung lapar (gizi buruk), atau juga penyakit sosial, seperti penjaja sex komersial, gembel (pengemis) dan lain sebagainya, kemiskinan juga mengakibat-kan turunnya harga diri individu atau kelompok masyarakat. Secara psikologis orang miskin cenderung lebih sensitif, gampang tersinggung, kurang percaya diri bahkan gampang emosi, sehingga kondisi ini rawan dengan berbagai upaya pemanfaatan pihak ketiga yang menggunakannya sebagai alat untuk memancing kerusuhan di sebuah daerah, intinya kemiskinan memiliki keterkaitan cukup erat dengan stabilitas politik dan ekonomi sebuah daerah.

\footnotetext{
${ }^{7}$ Berbeda dengan pandangan Barat, dalam Piagam Madinah, konsep yang dianut adalah kerjasama, tolong menolong, hal tersebut dapat dipahami dari ketentuan dalam pasal 11. Selanjutnya dalam pasal 15, menekankan jaminan atau perlindungan Allah swt terhadap orangorang lemah dan orang-orang mukmin sebagai penolong dan pembela terhadap sebagian lainnya. Juga pada pasal 37 yang juga menekankan harus adanya kerjasama dan tolong menolong dalam menghadapi orang yang menyerang warga shahifah yang saling menasehati dan berbuat kebaikan. Muhammad Hamidullah, Introduction to Islam (Paris: Centre Culturel Islamique, 1969), h. 93.

${ }^{8}$ Anwar Ibrahim, Sistem Politik (Jakarta: Lentera, 2001), h. 25.
} 
Karena me-rupakan masalah pembangunan yang multidimensi, maka pemecahan kemiskinan harus melalui strategis yang komperhensif, terpadu, terarah dan berkesinambungan. Dari berbagai literatur yang mengupas tentang konsep kemiskinan, paling tidak ada dua macam konsep kemiskinan yang dapat kita terima sebagai rujukan, yaitu; kemiskinan absolut dan kemiskinan relatif. Konsep pertama kemiskinan absolut dirumuskan dengan membuat ukuran tertentu yang kongkrit (a fixed yardstick). Ukuran itu lazimnya berorientasi kebutuhan hidup dasar minimum anggota masyarakat (sandang, pangan dan papan). Masing-masing negara terlihat mempunyai batasan kemiskinan absolut yang berbeda -beda, sebab kebutuhan hidup dasar masyarakat yang dipergunakan sebagai acuan memang berlainan. Karena ukurannya dipastikan, maka konsep kemiskinan mengenal garis batas kemiskinan. Kemiskinan absolut juga dapat dilihat dari sejauhmana tingkat pendapatan pen duduk miskin tersebut mampu mencukupi kebutuhan pokoknya (basic needs), yaitu pangan, sandang, papan, kesehatan dan pendidikan. Kemampuan untuk membeli kebutuhan pokok ini diequivalenkan dengan daya belinya (nilai uang). Mereka yang tidak mampu membeli kebutuhan pokok tertentu sesuai standar minimal dianggap berada pada posisi dibawah garis kemiskinan. Konsep yang kedua kemiskinan relatif dirumuskan berdasarkan the idea of relative standart, yaitu dengan memperhatikan dimensi tempat dan waktu. Dasar asumsinya adalah kemiskinan pada suatu daerah tertentu berbeda dengan daerah tertentu lain nya, dan kemiskinan pada saat tertentu berbeda dengan waktu yang lain. Konsep kemiskinan relatif lazimnya diukur berdasarkan pertimbangan in term of judgment anggota masyarakat tertentu, dengan berorientasi pada derajat kelayakan hidup. Kemiskinan relatif dilihat berdasarkan persentase pendapatan yang diterima oleh pendapatan lapisan bawah. Mereka yang berada pada lapisan bawah dalam stratifikasi pendapatan nasional inilah yang dianggap miskin Sedikitnya ada dua macam perspektif yang lazim dipergunakan untuk mendekati masalah kemiskinan, yaitu; kemiskinan dalam perspektif kultural (the cultural perspective) dan kemiskinan dalam perspektif struktural atau situasional (the situasional perspective). Masing-masing perspektif tersebut memiliki tekanan, acuan dan metodologi tersendiri yang berbeda dalam menganalisa masalah 
kemiskinan. Perspektif kultural mendekati masalah kemiskinan pada tiga level analisis; individual, keluarga dan masyarakat. Pada level individual ditandai sifat yang lazim disebut a strong feeling of marginality, seperti; sikap apatisme, fatalisme, pasrah pada nasib, boros, tergantung dan inferior. Pada level keluarga ditandai oleh jumlah anggota keluarga yang besar dan free union or consensual marriages. Kemudian pada level masyarakat, terutama ditandai oleh tidak terintegrasinya secera efektif dengan insitusi-institusi masyarakat. Mereka sering kali memperoleh perlakuan sebagai obyek yang perlu digarap daripada sebagai subyek yang perlu diberi peluang berkembang. Kemudian perspektif struktural/situasional masalah kemiskinan sebagai dampak dari sistem ekonomi yang mengutamakan akumulasi kapital dan produk-produk teknologi modern. Penetrasi kapital antara lain mengejawantahkan dalam prog-ram pembangunan yang dinilai lebih mengutamakan pertumbuhan (growth) dan kurang memperhatikan pemerataan hasil-hasil pembangunan (development). Programprogram tersebut antara lain berbentuk intensifikasi, ekstensifikasi dan komersialisasi pertanian untuk menghasilkan pangan sebesar-besar nya guna memenuhi kebutuhan nasional dan eksport. Masalah kemiskinan yang terjadi saat ini tidak bisa dilepaskan dari meningkatnya jumlah pengangguran. Pada masa krisis ekonomi ini, bukan saja laju pertambahan angkatan kerja baru tidak bisa diserap oleh pasar kerja, melainkan juga terjadi pemutusan hubungan kerja di sektor formal yang berakibat bertambahnya angkatan kerja yang menganggur, baik itu yang menganggur penuh atau sama sekali tidak bekerja (open unemployment) maupun setengah menganggur atau bekerja dibawah jam kerja normal (under unemployment).

\section{PERMASALAHAN DASAR KEMISKINAN}

Kemiskinan adalah "keadaan dimana terjadi ketidakmampuan untuk memenuhi kebutuhan dasar seperti makanan, pakaian, tempat berlindung, pendidikan, dan kesehatan. Kemiskinan dapat disebabkan oleh kelangkaan alat pemenuh kebutuhan dasar, ataupun sulitnya akses terhadap pendidikan dan pekerjaan. Selain itu kemiskinan juga dapat terjadi akibat adanya 
ketidakseimbangan dalam perolehan atau penggunaan sumber daya alam atau dengan kata lain terjadi dstribusi produksi yang tidak merata. Kemiskinan merupakan masalah global. Sebagian orang memahami istilah ini secara subyektif dan komparatif, sementara yang lainnya melihatnya dari segi moral dan evaluatif, dan yang lainnya lagi memahaminya dari sudut ilmiah yang telah mapan. Kemiskinan di Indonesia, berdasarkan data dari www.bps.go.id angka kemiskinan di Indonesia mencapai angka 32,53 juta penduduk atau sekitar 14,15\% dari seluruh jumlah penduduk Indonesia, kedengarannya cukup ironis, Indonesia yang subur dengan berbagai kekayaan alam, mengapa rakyat miskin begitu banyak, ada beberapa hal yang menyebabkan kemiskinan yang melanda di Indonesia antara lain: 1. Kualitas sumber daya manusia Seorang manusia tidak akan menjadi miskin jika memiliki kualitas yang baik, memiliki keterampilan (skill), pendidikan yang bagus dan hal lain yang akan membuatnya menjadi seseorang yang dibutuhkan dan mempunyai kemampuan, di Indonesia perma-salahan pendidikan belum teratasi sepenuhnya, walaupun anggaran untuk pendidikan menjadi perhatian dan sudah ditingkatkan ttetapi tetap saja masalah pendidikan masih belum bisa teratasi secara keseluruhan, hal ini juga yang menyebabkan masih banyak penduduk Indonesia yang tidak memiliki kualitas pendidikan bagus, maka dari itu bagaimana mau memiliki kualitas sumber manusia yang bagus jika manusianya tidak memiliki pendidikan yang bagus.lalu bagaimana pula mau mengolah kekayaan alam yang begitu melimpah ini jika SDMnya sendiri tidak mampu mengolahnya secara maksimal. 2. Sistem pemerintahan belum maksimal Salah satu penyebab lainnya dari kemiskinan adalah dari sitem pemerintahan, karena jika suatu sistem pemerintahan bekerja dengan maksimal, maka pemerataan kesejah-teraan rakyat pun akan tinggi, baik itu dari pendapatan perekonomian rata-rata, kualitas pendidikan dan lainnya yang merupakan faktor penentu kesejahteraan itu sendiri, lalu bagaimana dengan di Indonesia, mungkin kita semua sudah tahu bagaimana sistem pemerintahan yang ada di Indonesia, memang semua kebijakan terdengar bagus dan dirasa dapat menanggulangi masalah kemiskinan tersebut, tapi dalam kenyataan kebijakan yang dilahirkan belum mampu diwujudkan, karena angka kemiskinan itu masih tinggi. Hal ini disebabkan karena sistem pemerintahan belum 
maksimal dijalankan. yang membuat anggaran untuk menanggulangi kemiskinan tidak terealisasi secara maksimal pula, belum lagi kinerja DPR kita yang akhirakhir ini melakukan hal-hal kontroversial yang dirasa tidak perlu oleh masyarakat, padahal DPR adalah lembaga legislatif yang sangat berpengaruh terhadap pemerintahan di Indonesia.

\section{BANYAKNYA JUMLAH PENGANGGURAN}

Salah satu hal yang juga menyebabkan kemiskinan adalah pengangguran, seseorang bisa menjadi miskin jika tidak mampu menghasilkan sesuatu untuk memenuhi kebutuhan hidupnya, dan tingkat pengangguran di Indonesia bisa dibilang cukup tinggi, berikut kutipan dari http://koranindonesia.com. Lembaga Ilmu Pengetahuan Indonesia (LIPI) memproyeksikan angka pengangguran pada 2009 naik menjadi 9\% dari angka pengangguran 2008 sebesar 8,5\%. Kenaikan angka pengangguran disebabkan semakin merosotnya sumbangan sektor tradable dari 34,9\% pada kuartal II 2007 kemudian turun menjadi 26,6\% pada kuartal II 2008. ${ }^{9}$ Menurutnya, penurunan peran sektor tradable dalam pertumbuhan ekonomi memperlihatkan terjadinya proses pelemahan performa sektor tradable. Pertumbuhan sektor pertambangan dan galian serta industri pengolahan mengalami penurunan, bahkan untuk sektor pertambangan dan galian mengalami pertumbuhan yang negatif. Demikian halnya sektor pertanian, meski tumbuh relatif baik, tetapi lebih banyak didorong oleh pertumbuhan sub sektor tanaman bahan makanan dan peternakan, yang nota bene lebih mampu menyediakan kesempatan kerja, justru mengalami pertumbuhan yang negatif, masing-masing minus 5\% dan minus 3\%. ${ }^{10}$ Begitu juga target angka kemiskinan $12-14 \%$ pada 2009. Kalau turun $1 \%$ saja angka kemiskinan $15,4 \%$ pada 2008 , berapa juta orang yang harus dikeluarkan dari kemiskinan. Sementara, penyerapan tenaga kerja besar-besaran tidak ada. Karena LIPI menilai pertumbuhan ekonomi Indonesia pada kuartal II 2008 sebesar 6,4\% tidak berkualitas meski angka pertumbuhan

\footnotetext{
${ }^{9}$ Kenaikan angka pengangguran 2009 karena penyerapan tenaga kerja dari sektor industri tumbuh negatif, kata Peniliti Pusat Penelitian Ekonomi (P2E) LIPI Latif Adam saat melakukan jumpa pers bertajuk Pertumbuhan Ekonomi Naik, Industri Stagnan di gedung LIPI, Jakarta, Kamis, 28 Agustus 2008 http://koranindonesia.com

${ }^{10}$ Ibid
} 
ekonomi lebih tinggi dibandingkan dengan pertumbuhan ekonomi kuartal II 2007 yang hanya tumbuh sebesar 6,3\%. Pasalnya, sebagaimana yang terjadi dalam beberapa tahun terakhir, motor penggerak pertumbuhan ekonomi pada kuartal II 2008 masih tetap terfokus pada sektor non tradable dari berita tersebut dapat disimpulkan kalau pengangguran di Indonesia cukup tinggi, bahkan mengalami peningkatan dari tahuntahun sebelumnya.

\section{STRATEGI PENANGGULANGAN KEMISKINAN}

Ada dua agenda besar yang mesti dilakukan oleh para pengambil kebijakan, baik ditingkat lokal, maupun regional dalam program pengentasan kemiskinan yaitu, pertama; peningkatan kualitas Sumber Daya Manusia (SDM) melalui pendidikan dan keterampilan; dan kedua pembangunan ketenagakerjaan melalui perluasan lapangan kerja dan serangkaian program pembangunan padat karya. Program peningkatan kualitas sumber daya manusia dilakukan melalui pengembangan budaya usaha masyarakat miskin, yaitu mengembangkan budaya usaha yang lebih maju, mengembangkan jiwa kewirausahaan (enterpreneurship) dan meningkatkan keterampilan keluarga dan kelompok miskin untuk melakukan usaha ekonomi rakyat yang produktif atas dasar sikap demokratis dan mandiri. Program ketenagakerjaan dilakukan untuk menyediakan lapangan kerja dan lapangan usaha bagi setiap angkatan kerja sehingga dapat memperoleh pekerjaan dan penghidupan yang layak bagi kemanusiaan. Formula yang dapat diterapkan adalah dengan membangun iklim investasi yang kondusif disemua tingkatan, baik lokal, regional maupun nasional. Sebagaimana yang kita pahami bahwa investasi sekecil apapun jika regulasi dan iklim investasi tidak kondusif dan rasional, maka jangan harap investasi akan datang. Maka solusinya adalah harus political will dari pemerintah untuk memperbaiki iklim investasi se rasional mungkin. Islam memandang kemiskinan itu sangat bisa mendekatkan kepada kekufuran, sehingga harus diusahakan untuk dilenyapkan, minimal dikurangi. Dalam upaya mengentaskan kemiskinan, sumber yang paling pokok adalah dari zakat. Selain kewajiban mengeluarkan zakat bagi kaum muslim yang mampu juga dianjurkan untuk bersedekah dan membelanjakan harta pada jalan Allah, yakni adanya pada 
delapan ashnap bagi penerima zakat, termasuk menyantuni para fakir dan miskin. Ada terdapat banyak jenis zakat. Zakat itu meliputi zakat harta ${ }^{11}$ zakat fitrah. ${ }^{12}$ Menurut ulama Mazhab Maliki, Imam Ahmad bin Hambal, Ibnu Taimiyah dan Ibnu Qayyim al-Jauziyah, bahwa zakat fitrah hanya untuk orang-orang fakir dan miskin saja. Berbeda dengan mazhab Syafie $i$ yang berpendapat bahwa zakat fitrah juga selain untuk kedelapan golongan yang tersebut dalam QS. At-Taubah/9: 60, bukan hanya untuk golongan fakir miskin saja. Selain zakat sebagai salah satu ketentuan dalam hukum tentang puasa, adalah 1. Bagi perempuan hamil atau sedang menyusui anaknya; 2. Orang tua yang sudah tidak sanggup puasa; 3. Para pekerja betat seperti buruh; 4. Orang sakit bertahun-tahun dan tidak ada harapan akan sembuh, tidak diwajibkan berpuasa tetapi dibebani kewajiban untuk membayar fidyah berupa memberi makan untuk seorang fakir miskin setiap hari. Jadi selama bulan puasa setiap hari masing-masing memberi makan satu orang fakir atau miskin. ${ }^{13}$

Masih berkaitan dengan bulan Ramadhan, apabila ada suami-istri yang wajib puasa, melakukan hubungan suamiistri siang hari pada bulan Ramadhan, maka sanksi atas perbuatan mereka itu adalah :1. Memerdekakan budak, 2. Berpuasa dua bulan berturut-turut tanpa terputus, 3. Memberi makan enam puluh orang miskin. ${ }^{14}$ Dalam pelaksanaan ibadah haji sebagai rukun Islam kelima, para jama ${ }^{e e}$ h disunatkan menyembelih hewan untuk qurban. Daging hewan kurban tersebut diperuntukkan bagi golongan yang miskin. ${ }^{15}$ Selain dari beberapa faktor di atas yang bisa dijadikan sumber bantuan bagi kaum fakir miskin juga ada ganimah atau harta rampasan perang yang juga ada diperuntukkan bagi anak-anak yatim

${ }^{11}$ Zakat harta meliputi zakat emas dan perak, zakat hasil perdagangan (tijarah), zakat tumbuh-tumbuhan (nabat), zakat hewan, zakat logam (mae din), zakat benda-benda yang dihasilkan dari laut. Lihat Muhammad Alim, Asas-asas Negara Hukum Modern dalam Islam (Kajian Komprehensif Islam dan Ketatanegaraan), Cetakan I (Yogyakarta: LKIS, 2010, h. 240.

${ }^{12}$ Khusus zakat fitrah adalah sedekah harta yang dikeluarkan untuk memberikan kepada orang-orang yang berhajat, untuk mensucikan diri dan menutupi kekurangan-kekurangan yang telah terjadi pada puasa dan sebagai manifestasi bagi kesempurnaan nikmat puasa dan kasih sayang kepada fakir miskin. Muhammad Alim, 2010, h. 240

${ }^{13}$ Lihat Muhammad Hasbi Ash-Shiddieqy, Pedoman Zakat (Semarang: Pustaka Rizki Putra, t.t.), h. 100-1

${ }^{14}$ Lihat Muhammad Hasbi Ash-Shiddieqy, Pedoman Pua

${ }^{15}$ Lihat Muhammad Hasbi AshShiddieqy, Pedoman Haji (Semarang: Pustaka Rizki Putra, t.t.), h. 207 . 
dan orangorang miskin. Kesemuanya merupakan suatu kepedulian Islam terhadap kaum miskin sebagai nsalah satu cara untuk mengentaskan dari kemiskinan.

\section{HAK ATAS KESEJAHTERAAN}

Dalam Undang-undang Nomor 39 Tahun 1999 tentang Hak Asasi Manusia dijelaskan bahwa hak atas kesejahteraa yaitu: "Setiap orang berhak mempunyai milik, baik sendiri maupun bersama-sama dengan orang lain demi pengembangan dirinya, bangsa dan masyarakat dengan cara tidak melanggar hukum serta mendapatkan jaminan sosial yang dibutuhkan, berhak atas pekerjaan, kehidupan yang layak dan berhak mendirikan serikat pekerja demi melindungi dan memperjuangkan kehidupannya" Berbeda dengan pandangan kaum sekuler yang melihat kesejahteraan sematamata pada aspek pemenuhan kebutuhan duniawi. Pemikiran kaum sekuler menganggap manusia sebagai pusat dan ukuran segalanya; antroposentris. Dalam perspektif Islam, kesejahteraan bukan hanya untuk memenuhi kebutuhan duniawi, namun juga pemenuhan kebutuhan kebahagiaan di akhirat. Islam memandang Tuhan adalah ukuran segala-galanya; teorisentris. Maka dalam tolok ukur kesejahteraan manusia adalah kesejahteraan yang sesuai dengan nilai-nilai ilahiyah dan insaniyah. ${ }^{16}$ Tidak sama dengan falsafah golongan sekuler yang menitik beratkan pada pemenuhan kebutuhan fisik semata. Islam sangat menjaga keseimbangan kebutuhan mental dan fisik, rohani dan jasmani. Begitu pula untuk mencapai kesejahteraan tersebut. Barat mengandalkan pada kesejahteraan orang per orang secara individual, maka Islam menghendaki mencapai kesejahteraan dengan kebersamaan, kolektif, keadilan sosial dan ekonomi bagi seluruh anggota masyarakat. ${ }^{17}$ Dalam bidang ekonomi, satu catatan prestasi yang pernah dicapai tahap ideal yang sebelumnya belum pernah dicapai oleh negara manapun di dunia, termasuk negaranegara Barat dalam hal kesejahteraan masyarakatnya. Adalah Khalifah Umar bin Abdul Azis sebagai

\footnotetext{
${ }^{16}$ Secara normatif, kolektifisme dalam Islam sudah tampak pada penyaluran zakat kepada delapan bagian sebagaimana tersebut dalam QS. At-Taubah/9: 60. Kedelapan bagian yang kepadanya disalurkan zakat, ini semua bertujuan untuk kesejahteraan Lihat Azhari, Negara Hukum (Jakarta: 2000), h. 107.

${ }^{17}$ Muhammad Alim, Asas-asas Negara Hukum Modern dalam Islam (Kajian Komprehensif Islam dan Ketatanegaraan) 2010, h. 240.
} 
dokumen sejarah yang menakjubkan. Pada alinea keempat Pembukaan dan Pasal 28 c ayat (1) Undang-undang Dasar 1945, Hak atas kesejahteraan tidak diatur dalam Universal Declaration of Human Rights, hak atas kesejahteraan diatur juga dalam pasal 17 c The Cairo Declaration on Human Rights in Islam. Pasal 34 ayat (1) UUD 1945 hasil amandemen keempat disebutkan bahwa "fakir miskin dan anak terlantar dipelihara oleh negara". Perlindungan hak-hak anak juga diatur dalam sejumlah undang-undang yang terkait yaitu Undang-Undang Nomor 1 Tahun 1974 tentang Perkawinan, UndangUndang Nomor 4 Tahun 1979 tentang Kesejahteraan Anak, UU Nomor 39 Tahun 1999 tentang Hak Asasi Manusia, dan Undang-Undang Nomor 23 Tahun 2002 tentang Perlindungan Anak serta Instruksi Presiden Nomor 1 Tahun 1991 tentang Kompilasi Hukum Islam. Namun dalam kenyataannya jumlah anak terlantar dan anak jalanan di Sumatera Utara semakin banyak dan implementasi peraturan perundang-undangan tersebut terhadap perlindungan hak-hak anak belum diterapkan sebagaimana mestinya, baik terhadap anak terlantar di panti asuhan maupun terhadap anak terlantar yang turun ke jalan untuk mencari uang dengan cara memintaminta, tukang asongan, tukang semir sepatu, untuk memenuhi nafkah orang tuanya dan untuk biaya hidupnya.

Padahal dalam Pasal 28 B ayat (2) Undang-Undang Dasar 1945 hasil amandemen kedua disebutkan "setiap anak berhak atas kelangsungan hidup, tumbuh, dan berkembang serta berhak atas perlindungan dari kekerasan dan diskriminasi". Tujuan dalam penelitian ini adalah untuk mengkaji undang-undang perlindungan anak belum dapat memberikan perlindungan hukum terhadap hakhak anak, hambatan-hambatan dan sebab-sebab yang terjadi dalam penerapan perlindungan hukum terhadap hak-hak anak, dan peran pemerintah daerah dalam mewujudkan peraturan dan undang-undang perlindungan anak terhadap hak-hak anak. Untuk mengkaji hal-hal tersebut di atas, dilakukan penelitian dalam bentuk preskriptif analitis dengan pendekatan yuridis normatif dan pendekatan yuridis sosiologis. Dengan demikian rakyat, berhak atas kesejahteraan dan pemerintah berkewajiban memajukan kesejahteraan umum, mencerdaskan kehidupan rakyat, umat, bahkan harus aktif dalam semua aspek kehidupan ke arah kesejahteraan seluruh masyarakat. Simpulan Dalam Piagam Madinah, konsep yang dijalankan 
adalah sistem kerjasama, tolong menolong. Apabila zakat sebagai salah satu strategi dalam pemenuhan hak atas kesejahteraan dibandingkan dengan pajak di negara-negara lainnya, yang dari padanya sebagai salah sumber anggaran pendapatan suatu negara. Penggunaan zakat disamakan dengan belanja negara, maka dalam anggaran pendapatan dan belanja negara (APBN) negara Madinah dengan mendasar pada QS. At-Taubah/9:60. Dari delapan golongan yang berhak mendapat anggaran belanja negara, urutan terdepan ditempati orang-orang fakir, sesudah itu orang-orang miskin dan seterusnya. Jadi dalam APBN Negara Madinah dan lainnya pengentasan kefakiran dan kemiskinan termasuk dalam skala prioritas yang tinggi dengan perhatian yang cukup besar.

\section{DAFTAR PUSTAKA}

Abd. Shamad, Akad Mudharabah dalam Perbankan Syarieeah, Yuridika, vol. 16, No. 4, Juli - Agustus 2001.

Alim, Muhammad, Asas-asas Negara Hukum Modern dalam Islam (Kajian Komprehensif Islam dan Ketatanegaraan) Yogyakarta, LKIS, 2010.

Azhari, Negara Hukum, Jakarta: 2000

Ensiklopedia Hukum Islam Jakarta: PT. Ichtiar Baru van Hoeve, 2000.

Fakih, Mansour, Runtuhnya Teori Pembangunan dan Globalisasi, Yogyakarta: INSIST Press dan Pustaka Pelajar, 2002.

Hamidullah, Muhammad, Introduction to Islam, Paris : Centre Culturel Islamique, 1969

Hasbi Ash-Shiddieqy, Muhammad, Pedoman Haji, Semarang: Pustaka Rizki Putra, t.t

Hasbi Ash-Shiddieqy, Muhammad, Pedoman Puasa, Semarang: Pustaka Rizki Putra, t.t.

Hasbi Ash-Shiddieqy, Muhammad, Pedoman Zakat, Semarang: Pustaka Rizki Putra, t.t.

Khan, Adnan, Kapitalisme di Ujung Tanduk: Tinjauan atas Krisis Global, Krisis Minyak, Krisis Pangan dan Bagaimana Sistem Ekonomi Islam Mengatasinya (The Global Credit Crunch and The Crisis of Capitalism), 